\title{
Prognostic Value of the Right Ventricle Diameter, Pulmonary Arterial Pressure and Biomarkers in Patients with Acute Heart Failure
}

\author{
Dejan Petrović1,2, Marina Deljanin-Ilić, ${ }^{1,2}$, Sanja Stojanović², Dejan Simonović2, \\ Dijana Stojanović ${ }^{1}$, Valentina Mitić ${ }^{2}$, Milovan Stojanović ${ }^{2}$ \\ ${ }^{1}$ University of Nis, Faculty of Medicine, Niš, Serbia \\ 2Institute for Treatment and Rehabilitation "Niška Banja", Niška Banja, Serbia
}

\author{
SUMMARY
}

The aim of the paper was to examine the echocardiographic parameters of the right ventricle (RV), its diameter and pulmonary arterial pressure (PAP); to determine their relationship to B-type natriuretic peptide (BNP), troponin and (TnI) and high-sensititity C-raective protein (hsCRP), and to evaluate their prognostic significance to one-year mortality in patients with acute heart failure (AHF).

The study included a total of 225 patients (pts) $(70.29 \pm 9.74$ years) who were admitted to Intensive care unit due to the signs and symptoms of AHF. The values of standard biochemical parameters, BNP, TnI and hsCRP were determined during the first 24 hours after admission. All patients underwent echocardiographic examination.

During a one-year follow-up, $78(34.70 \%)$ patients died. As compared with the group of survivors $(\mathrm{n}=147)$, the group of non-survivors had higher values of BNP $(853.10 \pm 384.92 \mathrm{vs} .1399 .68 \pm 464.44 \mathrm{pg} / \mathrm{mL}, \mathrm{p}$ $<0.001)$, TnI $(0.59 \pm 2.04$ vs. $2.00 \pm 8.29 \mathrm{ng} / \mathrm{ml}, \mathrm{p}<0.05)$, right ventricular diameter and PAP $(\mathrm{p}<0.001)$. BNP was positively correlated with TnI $(\varrho=0.311)$, PAP $(\varrho=0.255)$ and right ventricular diameter $(\varrho=0.304, p<$ 0.001 for all correlations). The cut-off value of BNP $\geq 1062.04 \mathrm{pg} / \mathrm{ml}, \mathrm{PAP} \geq 44.5 \mathrm{mmHg}$ and TnI $\geq 0.04 \mathrm{ng} / \mathrm{ml}$ were associated with a higher risk of mortality.

Our results have shown that BNP, PAP and TnI are strong and independent predictors of one-year mortality in hospitalized patients with acute heart failure.

Key words: acute heart failure, biomarkers, pulmonary arterial pressure, right ventricle diameter 


\section{INTRODUCTION}

There is a very high mortality rate in acute heart failure (AHF), so that clinical risk assessment after AHF hospitalization still represents a relevant challenge $(1,2)$. All-cause mortality is generally higher in heart failure with reduced ejection fraction (HFrEF) than heart failure with preserved ejection fraction (HFpEF) (3). The symptoms of AHF are not specific, which is the reason for occasional delayed diagnosing (3), especially when the information is obtained by applying the standardized approach, which includes physical examination, electrocardiography and chest X-ray (4).

Blood levels and determination of B-type natriuretic peptide (BNP) and N-terminal pro hormone BNP (NT-proBNP) represents the gold standard for the diagnosis and prognosis in patients with acute dispnea (5). However, certain factors such as age, sex, race, body mass index and renal function, can have a negative impact on the accuracy of the BNP test (6). So far, the results of the researches have shown that echocardiographic determinants of the left ventricle (ejection fraction, end-diastolic and end-systolic volume) are independant predictors of the mortality in patients with AHF (7).

Untill now, only few studies have investigated the right ventricle (RV) echocardiographic parameters and their significance in predicting the mortality of patients with AHF. In addition, a few studies have investigated a correlation of these parameters with heart failure (HF) biomarkers such as BNP and NTproBNP (8).

The aim of the present study was to examine the echocardiographic parameters of RV, its diameter and pulmonary arterial pressure (PAP); to determine their relationship to BNP, Troponin I (TnI) and high-sensititity C-raective protein (hsCRP), and to evaluate their prognostic significance to one-year mortality in patients with AHF.

\section{PATIENTS AND METHODS}

This prospective study included 225 consecutive patients, admitted to the Intensive Care Unit of the Institute for Treatment and Rehabilitation "Niška Banja", Cardiology Clinic, from July 1, 2016 to July 1, 2018. All patients had the signs and symptoms of AHF. Ethics Committee of the Institute for Treatment and Rehabilitation "Niška Banja" approved the study; also, every patient signed an informed con- sent before entering the trial. The diagnosis of AHF was made according to the ESC guidelines for AHF (9). Also, the same diagnosis of AHF had to be confirmed on patient discharge. In each patinet, during the first hospital day, standard laboratory analysis and analysis of specific biomarkers (BNP, TnI and hsCRP - ELISA method) were done.

During the first 48 hours of hospitalization, echocardiographic examination was performed in all patients (Esaote Mylab Alpha 60 echomachine; two experienced cardiologists), according to Europaen Society of Echocardiography guidelines (10). Also, 24-hour Holter monitoring (Del Mar) was performed in all patients, as well as the analyses of the frequency and complexity of ventricular arrhythmias and heart rate variability parameters.

After being discharged from the hospital, the patients were monitored for the following 12 months.

For statistical analysis, we used Chi-square $\left(\chi^{2}\right)$-test, Student's t-test, and Mann-Whitney U-test. Data are presented as frequencies or means with standard deviation (SD). The correlations analysis were determined by Spearman's correlation. Oneyear mortality of AHF was determined by multivariate logistic regression analysis and multivariate Cox's regression analysis after correction for confounders (age, sex, systolic blood pressure, renal function, therapy). Testing for biomarkers (BNP, TnI) and PAP as predictors of mortality was estimated using ROC (receiver operating characteristics) curves by calculating the area under the curve and by determining the statistical significance. The cutoff was determined as the value of the product of optimal sensitivity and specificity. Statistical analyses was performed using the Statistical Package for Social Sciences (SPSS-20; Chicago, IL, USA) for the level of statistical significance of $p<0.05$.

\section{RESULTS}

The study included 225 patients, 146 men $(65 \%)$ and 79 women $(35 \%)$, mean age $70.29 \pm 9.74$ years. During a one-year follow-up, $78(34.70 \%)$ patients died. The most frequent cause of AHF in the observed population was the coronary disease (55\%), followed by valvular diseases (19\%) and dilated cardiomyopathia of unknown etiology (19\%).

Demographic, clinical and biochemical characteristics of the whole cohort and comparison of the analyzed data between the examined groups (one- 
Table 1. Baseline demographic, clinical and biochemical characteristics (total cohort and according one-year survival)

\begin{tabular}{|c|c|c|c|c|}
\hline Parameters & $\begin{array}{c}\text { Total } \\
\mathrm{N}=225\end{array}$ & $\begin{array}{c}\text { Non-survivors } \\
\mathrm{N}=78 \\
\end{array}$ & $\begin{array}{c}\text { Survivors } \\
\mathrm{N}=\mathbf{1 4 7}\end{array}$ & $\begin{array}{c}p \\
\left(\eta^{2}\right)\end{array}$ \\
\hline Age (years) & $70.29 \pm 9.74$ & $70.24 \pm 10.20$ & $70.31 \pm 9.52$ & 0.960 \\
\hline $\operatorname{Sex}(M / W)$ & $146 / 79$ & $52 / 26$ & $94 / 53$ & 0.770 \\
\hline Number of previous hospitalizations & $1.46 \pm 1.65$ & $1.72 \pm 1.75$ & $1.33 \pm 1.59$ & 0.091 \\
\hline $\mathbf{B N P}(\mathrm{pg} / \mathrm{mL})$ & $1042.58 \pm 488.55$ & $1399.68 \pm 464.44$ & $853.10 \pm 384.92$ & $<0.001$ \\
\hline TnI (ng/mL) & $1.08 \pm 5.18$ & $2.00 \pm 8.29$ & $0.59 \pm 2.04$ & 0.048 \\
\hline hsCRP (mg/L) & $11.16 \pm 12.09$ & $12.72 \pm 10.00$ & $10.33 \pm 13.02$ & 0.159 \\
\hline PAP $(\mathrm{mmHg})$ & $43.41 \pm 10.20$ & $49.67 \pm 10.65$ & $40.09 \pm 8.24$ & $<0.001$ \\
\hline $\operatorname{RVEDD}(\mathrm{mm})$ & $28.43 \pm 4.96$ & $31.09 \pm 5.60$ & $27.02 \pm 3.93$ & $<0.001$ \\
\hline LVEF $(\%)$ & $32.31 \pm 11.38$ & $27.45 \pm 10.73$ & $34.89 \pm 10.87$ & $<0.001$ \\
\hline $\mathbf{S B P}(\mathrm{mmHg})$ & $135.02 \pm 25.41$ & $124.23 \pm 24.75$ & $140.75 \pm 23.93$ & $<0.001$ \\
\hline DBP $(\mathrm{mmHg})$ & $82.04 \pm 14.44$ & $77.24 \pm 14.59$ & $84.59 \pm 13.74$ & $<0.001$ \\
\hline $\operatorname{HR}(\mathrm{R} / \mathrm{min})$ & $92.22 \pm 23.60$ & $87.18 \pm 22.73$ & $94.89 \pm 23.70$ & 0.019 \\
\hline BMI $\left(\mathrm{kg} / \mathrm{m}^{2}\right)$ & $27.41 \pm 4.88$ & $27.19 \pm 4.66$ & $27.92 \pm 5.38$ & 0.479 \\
\hline GFR (mL/min) & $60.86 \pm 28.26$ & $64.29 \pm 27.40$ & $59.40 \pm 28.65$ & 0.373 \\
\hline TC $(\mathrm{mmol} / \mathrm{L})$ & $4.62 \pm 1.35$ & $4.65 \pm 1.43$ & $4.56 \pm 1.17$ & 0.702 \\
\hline LDL-C (mmol/L) & $3.00 \pm 1.09$ & $3.04 \pm 1.16$ & $2.90 \pm 0.88$ & 0.465 \\
\hline HDL-C (mmol/L) & $1.09 \pm 0.35$ & $1.10 \pm 0.34$ & $1.05 \pm 0.37$ & 0.519 \\
\hline TG $(\mathrm{mmol} / \mathrm{L})$ & $1.41 \pm 0.87$ & $1.42 \pm 0.97$ & $1.39 \pm 0.61$ & 0.807 \\
\hline Ventricular arrhythmias & $43(34.70)$ & $32(36.80)$ & $11(29.70)$ & 0.538 \\
\hline Hypotension & $18(15)$ & $2(11)$ & $16(89)$ & 0.043 \\
\hline
\end{tabular}

BNP = B-type natriuretic peptide, $\mathbf{T n I}=$ Troponin-l, hs-CRP $=$ High-sensitivity C-reactive protein, $\mathbf{P A P}=$ Pulmonary arterial pressure, RVEDD $=$ End-diastolic diameter right ventricular, $\mathbf{L V E F}=$ Ejection fraction left ventricule, SBP $=$ Systolic blood pressure, $\mathbf{D B P}=$ Diastolic blood pressure, $\mathbf{H R}=$ Heart rate, $\mathbf{B M I}=$ Body mass index, $\mathbf{G F R}=$ Glomerular filtration rate, $\mathrm{TC}=$ Total cholesterol, $\mathbf{L D L}=$ Low-density lipoprotein cholesterol, HDL-C $=$ High-density lipoproteins cholesterol, $\mathbf{T G}=$ Triglyceride

Table 2. Correlation between biomarkers ( $B N P, T n I$, hsCRP), right and left ventricular parameters (Spearman's coefitients)

\begin{tabular}{c|c|c|c|c|c|c}
\hline \hline Parameters & BNP & TnI & hsCRP & PAP & RVEDD & LVEF \\
\hline BNP & - & $0.311^{* * *}$ & 0.082 & $0.255^{* *}$ & $0.304^{* *}$ & $-0.459^{* * *}$ \\
\hline TnI & $0.311^{* * * *}$ & - & $0.163^{*}$ & 0.091 & 0.097 & $-0.131^{*}$ \\
\hline hsCRP & 0.082 & $0.163^{*}$ & - & $0.168^{*}$ & $0.168^{*}$ & $-0.131^{*}$ \\
\hline PAP & $0.255^{* * *}$ & 0.091 & $0.168^{*}$ & - & $0.685^{* *}$ & $-0.212^{* *}$ \\
\hline RVEDD & $0.304^{* * * *}$ & 0.097 & $0.168^{*}$ & $0.685^{* *}$ & - & $-0.285^{* * *}$ \\
\hline LVEF & $-0.459^{* * *}$ & $-0.131^{*}$ & $-0.131^{*}$ & $-0.212^{* *}$ & $-0.285^{* * *}$ & - \\
\hline
\end{tabular}

BNP = B-type natriuretic peptide, $\mathbf{T n I}=$ Troponin-l, hs-CRP = High-sensitivity C-reactive protein, $\mathbf{P A P}=$ Pulmonary arterial pressure, RVEDD = End-diastolic diameter right ventricular, LVEF = ejection fraction left ventricule 
year survival) are shown in Table 1.

The mean age of the deceased was $70.24 \pm$ 10.20 years, while the mean age of survivors was $70.31 \pm 9.52$ years (non-sig.). The group of non-survivors compared to the group of survivors had higher values of BNP (853.10 \pm 384.92 vs $1399.68 \pm$ $464.44 \mathrm{pg} / \mathrm{mL}, \mathrm{p}<0.001)$, hsCRP $(10.33 \pm 13.02$ vs $12.72 \pm 10.0 \mathrm{mg} / \mathrm{L}, \mathrm{ns})$, TnI $(0.59 \pm 2.04$ vs $2.00 \pm 8.29$ $\mathrm{ng} / \mathrm{ml}, \mathrm{p}<0.05)$, right ventricular diameter (27.02 \pm 3.93 vs $31.09 \pm 5.60 \mathrm{~mm}, \mathrm{p}<0.001)$ and PAP $(40.09 \pm$ 8.24 vs $49.67 \pm 10.65 \mathrm{mmHg}, \mathrm{p}<0.001)(11)$.

The relationship between $\mathrm{BNP}, \mathrm{TnI}$ and hsCRP, and certain parameters of the left and right ventricular function are presented in Table 2.

A positive linear correlation was found between BNP and TnI ( $\mathrm{Q}=0.311), \mathrm{BNP}$ and PAP ( $\mathrm{Q}=$ $0.255)$ and BNP and right ventricular diameter $(\mathrm{Q}=$ $0.304), p<0.001$ for all correlations, hsCRP and ventricular function parameters $(\mathrm{Q}=0.168, \mathrm{p}<0.05)$. A significant negative correlation was found between BNP and LVEF ( $=-0.459, \mathrm{p}<0.05)$, TnI and hsCRP, and LVEF $(\varrho=-0.131, \mathrm{p}<0.05)(11)$, while there was no significant correlation between TnI and right ven- tricular function parameters (non-sig.).

Mean values of biomarkers (BNP, TnI, hsCRP) in relation to the right and left ventricular parameters PAP, RVEDD and LVEF are shown in Tables 3 and 4 .

Out of 225 patients, those with the right ventricular diameter RVEDD $\leq 30 \mathrm{~mm}(\mathrm{n}=158)$ had lower values of BNP than patients $(n=67)$ with the right ventricular diameter RVEDD > $30 \mathrm{mmHg}(928.25 \pm$ 235.84 vs.1312.19 $\pm 238.58 \mathrm{pg} / \mathrm{ml}, \mathrm{p}<0.001)$. The values of TnI and hsCRP were not significantly different between these groups of patients (Table 3 ).

Patients with PAP $<40 \mathrm{mmHg}(\mathrm{n}=104)$ and patients with $L V E F \geq 30 \%(n=122)$ had lower values of BNP (Table 4 ) than patients with PAP $\geq 40 \mathrm{mmHg}$ $(\mathrm{n}=121)$ and patients $(\mathrm{n}=103)$ with $\mathrm{LVEF}<30 \%(\mathrm{p}<$ 0.001 for all correlations). There was no statistically significant difference in values of biomarkers TnI and hsCRP in relation to RVEDD, PAP and LVEF.

By applying a multivariate logistic regression analysis, parameters shown in Table 5 (bold) were identified as independent predictors of mortality of AHF (Table 5).

Table 3. Values of BNP, TnI $i$ hsCRP in relation to RVEDD

\begin{tabular}{|c|c|c|c|c|}
\hline \multirow[b]{2}{*}{ Parameters } & \multirow{2}{*}{$\begin{array}{c}\text { Total } \\
\mathrm{N}=225\end{array}$} & \multicolumn{2}{|c|}{ RVEDD } & \multirow{2}{*}{$\begin{array}{c}\mathbf{P} \\
\text { value }\end{array}$} \\
\hline & & $\begin{array}{l}\leq \mathbf{3 0} \mathbf{~ m m} \\
\mathrm{N}=158\end{array}$ & $\begin{array}{c}>30 \mathrm{~mm} \\
\mathrm{~N}=67\end{array}$ & \\
\hline BNP (pg/ml) & $1042.58 \pm 188.55$ & $928.25 \pm 235.84$ & $1312.19 \pm 238.58$ & 0.001 \\
\hline TnI (ng/ml) & $1.08 \pm 0.52$ & $0.78 \pm 0.48$ & $1.78 \pm 0.70$ & 0.186 \\
\hline hsCRP (mg/l) & $11.16 \pm 2.09$ & $10.17 \pm 1.89$ & $13.48 \pm 2.73$ & 0.061 \\
\hline
\end{tabular}

Table 4. Values of BNP, TnI $i$ hsCRP in relation to PAP and LVEF

\begin{tabular}{l|c|c|c|c|c|c}
\hline \hline \multirow{2}{*}{ Parameters } & \multicolumn{3}{|c|}{ PAP } & \multicolumn{3}{c}{ LVEF } \\
\cline { 2 - 7 } & $<\mathbf{4 0 ~ \mathbf { m m H g }}$ & $\begin{array}{c}\mathbf{4 0} \mathbf{~ m m H g} \\
\mathrm{N}=104\end{array}$ & $\begin{array}{c}\mathbf{P} \\
\mathrm{N}=121\end{array}$ & $\begin{array}{c}<\mathbf{3 0} \% \\
\text { value }\end{array}$ & $\begin{array}{c}\mathbf{N}=103 \\
\mathrm{~N}=122\end{array}$ & $\begin{array}{c}\mathbf{P} \\
\text { value }\end{array}$ \\
\hline BNP $(\mathrm{pg} / \mathrm{ml})$ & $878.68 \pm 239.20$ & $1183.45 \pm 286.50$ & $\mathbf{0 . 0 0 1}$ & $1250.02 \pm 287.12$ & $867.45 \pm 207.52$ & $\mathbf{0 . 0 0 1}$ \\
\hline TnI $(\mathrm{ng} / \mathrm{ml})$ & $0.96 \pm 0.94$ & $1.18 \pm 0.72$ & 0.741 & $1.24 \pm 0.66$ & $0.95 \pm 0.49$ & 0.676 \\
\hline hsCRP $(\mathrm{mg} / \mathrm{l})$ & $10.24 \pm 1.73$ & $11.5 \pm 2.47$ & 0.292 & $12.24 \pm 2.45$ & $10.24 \pm 1.97$ & 0.218 \\
\hline \hline
\end{tabular}

Multivariate logistic regression analysis after adjustment (age, gender, etc) showed that higher values of BNP $(\mathrm{P}<0.001)$, PAP $(\mathrm{P}<0.001)$ and TnI $(\mathrm{P}$ $<0.01$ ) were independently associated with one-year mortality of AHF, while other parameters were not significant as predictors for mortality. The best and independent predictors for one-year mortality increased the risk as follows: BNP, PAP and TnI.

The parameters shown in Table 6 after adjustment (age, sex, etc) were distinguished as significant and independent predictors for one-year mortality: TnI $(p<0.01)$ and PAP $(p<0.001)$, while other pa- 
Table 5. Predictors of one-year mortality of AHF (Logistic regression analysis)

\begin{tabular}{c|c|c|c|c}
\hline \hline \multirow{2}{*}{ Parameter } & \multirow{2}{*}{ Sig. } & \multirow{2}{*}{ OR -} & \multicolumn{2}{|c}{$95 \%$ CI for EXP(B) } \\
\cline { 4 - 5 } & & Exp (B) & Lower & Upper \\
\hline BNP & $<\mathbf{0 . 0 0 1}$ & 1.003 & 1.002 & 1.004 \\
\hline TnI & $\mathbf{0 . 0 0 5}$ & 1.274 & 1.074 & 1.510 \\
\hline hsCRP & 0.307 & 1.019 & 0.983 & 1.056 \\
\hline SBP & 0.080 & 0.972 & 0.941 & 1.003 \\
\hline DBP & 0.313 & 1.026 & 0.976 & 1.078 \\
\hline PAP & $<0.001$ & 1.099 & 1.038 & 1.164 \\
\hline RVEDD & 0.919 & 1.005 & 0.909 & 1.112 \\
\hline LVEF & 0.950 & 0.999 & 0.959 & 1.040 \\
\hline HR & 0.077 & 0.985 & 0.968 & 1.002 \\
\hline \hline
\end{tabular}

Table 6. Predictors of one-year mortality of AHF (Cox regression analysis)

\begin{tabular}{l|c|c|c|c}
\hline \hline \multirow{2}{*}{ Parameter } & \multirow{2}{*}{ Sig. } & \multirow{2}{*}{ HR } & \multicolumn{2}{|c}{$95 \%$ CI for HR } \\
\cline { 4 - 5 } & & & Lower & Upper \\
\hline TnI & $\mathbf{0 . 0 0 2}$ & 1.047 & 1.018 & 1.078 \\
\hline hsCRP & 0.107 & 1.012 & 0.997 & 1.028 \\
\hline PAP & $<\mathbf{0 . 0 0 1}$ & 1.087 & 1.051 & 1.124 \\
\hline RVEDD & 0.058 & 0.932 & 0.867 & 1.003 \\
\hline \hline
\end{tabular}

BNP = B-type Natriuretic Peptide, TnI = Troponin1, hs-CRP = High-sensitivity $\mathrm{C}$-reactive protein, $\mathbf{S B P}=$ Systolic blood pressure, DBP $=$ Diastolic blood pressure, PAP = Pulmonary arterial pressure, RVEDD = Enddiastolic diameter right ventricular, $\mathbf{L V E F}=$ Ejection fraction left ventricule, $\mathbf{H R}=$ Heart rate.

Table 7. Predictive values of BNP, TnI and PAP for the prediction of one-year mortality

\begin{tabular}{c|c|c|c|c|c}
\hline \hline \multirow{2}{*}{$\begin{array}{c}\text { Test Result } \\
\text { Variable(s) }\end{array}$} & \multirow{2}{*}{$\begin{array}{c}\text { Area } \\
\text { (AUC) }\end{array}$} & \multirow{2}{*}{$\begin{array}{c}\text { Ssymptotic } \\
\text { Sig. }\end{array}$} & \multicolumn{3}{|c}{ Coordinates of the Curve } \\
\cline { 4 - 6 } & Cut-off value & Sensitivity (\%) & Specificity (\%) \\
\hline BNP $(\mathrm{pg} / \mathrm{ml})$ & 0.820 & $\mathbf{0 . 0 0 1}$ & 1062.04 & 74.4 & 72.8 \\
\hline TnI $(\mathrm{ng} / \mathrm{ml})$ & 0.696 & $\mathbf{0 . 0 0 1}$ & 0.04 & 68.6 & 65.3 \\
\hline $\mathbf{P A P}(\mathrm{mmHg})$ & 0.776 & $\mathbf{0 . 0 0 1}$ & 44.50 & 68.9 & 70.7 \\
\hline \hline
\end{tabular}

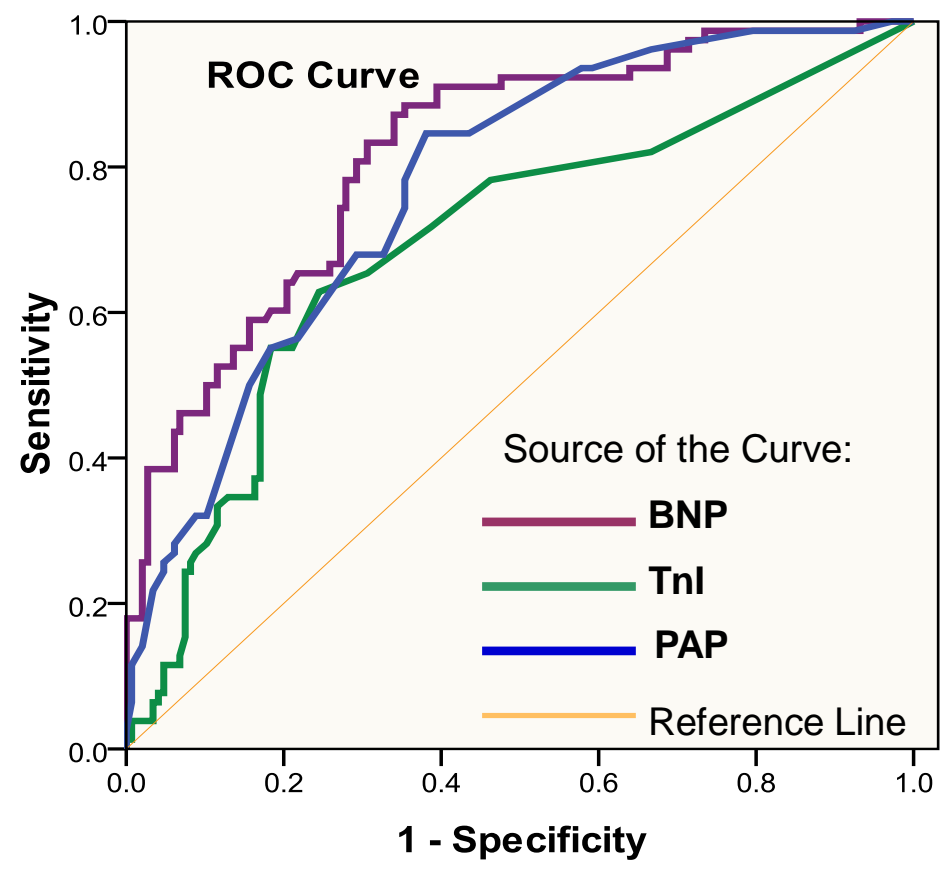

Figure 1. ROC curve of BNP, TnI and PAP for the prediction of one-year mortality

$\mathbf{B N P}=$ B-type natriuretic peptide, $\mathbf{T n I}=$ Troponin-l, $\mathbf{P A P}=$ Pulmonary arterial pressure 
rameters were not significant to be the predictors of one-year mortality. The best and independent predictors which increased the risk of one-year mortality are TnI and PAP.

The values of BNP, TnI and PAP for the prediction of one-year mortality were assessed by the ROC curve (Table 7, Figure 1).

Out of the tested biomarkers (BNP, TnI and hsCRP) for one-year mortality using ROC curves by calculating the area under the curve, BNP showed the best discriminant value.

The cut-off value of $\mathrm{BNP} \geq 1062.04 \mathrm{pg} / \mathrm{ml}$ was associated with a higher risk of mortality (AUC = $0.820, \mathrm{p}<0.001)$. Beside BNP, PAP $\geq 44.5 \mathrm{mmHg}$, as well as $\mathrm{TnI} \geq 0.04 \mathrm{ng} / \mathrm{ml}$ (AUC $=0.696, \mathrm{p}<0.001$ ), was also associated with a higher risk of mortality (AUC $=0.776, \mathrm{p}<0.001)(11)$.

\section{DISCUSSION}

The overall one-year mortality in our study group was very high $-34.7 \%$, and it was higher than in other studies that had a similar design (12). In our study, the analyses of BNP, TnI and hsCRP, and functional parameters of both ventricles (RVEDD, PAP, an LVEF) distinguished the concentrations of BNP, TnI, PAP and an LVEF as significant predictors of one-year mortality in patients hospitalized due to AHF.

Previous studies have shown that BNP is an independent predictor of mortality in patients with systolic and diastolic heart failure (13). The study by Peacock et al. (14), the results of which are similar to ours, shows that increased TnI levels have strong prognostic significance in predicting one- year mortality of patients hospitalized with the diagnosis of decompensated HF. It is known that slight increase in troponin can be expected in a serious HF (NYHA class III and IV), but also during the episodes of HF decompensation, as well as in the absence of the acute coronary syndrome and severe coronary artery disease. The fact that in our studied AHF population ischemic etiology of heart failure was present in 55\% of patients may be explained by a lower statistical significance of $\mathrm{TnI}$ prediction.

The results of a meta-analysis on 6,600 patients showed that there was a significant correlation between increased hsCRP level and adverse CV events, which implies mortality of patients with chronic HF, regardless of the etiology which may be ischemic or non-ischemic. However, there are not sufficient data on the prognostic significance of hsCRP in AHF (15). Unlike some studies (16), our results show that hsCRP is an independent predictor of mortality in patients with AHF.

It is shown that a combination of two HF biomarkers (eg, BNP and CRP and TnI or BNP) contributes to better risk stratification in patients with AHF than it was achieved with the use of a single biomarker (17).

Also, there are no studies that have dealt with simultaneous determining of the "cut-off" values of BNP or CRP and TnI as well as echocardiographic parameters of the left and right ventricle in assessing the severity and prognosis of patients with AHF. A $\mathrm{RV}-\mathrm{HF}$ is a HF caused by pulmonary hypertension or left-sided HF (18). Regardless of the HF etiology, increasing BNP can be a direct result of the increased pulmonary pressure and RV dysfunction (19). Our results show that $\mathrm{RV}$ dysfunction and consequent PAP increase significantly cause an increase in the value of BNP.

These results were first found by MarianoGoulart et al. (20) in patients with HF-RV. Also, in a recent study, Vogelsang et al. (19) have demonstrated the importance of BNP in detecting systolic dysfunction of the right ventricle independently of SI etiology.

The results of this study indicate that the parametric values of $\mathrm{BNP} \leq 1062.04 \mathrm{pg} / \mathrm{mL}, \mathrm{TnI} \leq 0.04$ $\mathrm{ng} / \mathrm{ml}$ and PAP $\leq 44.5 \mathrm{mmHg}$ are associated with a reduced risk of one-year mortality of hospitalized patients with HF. In our group of patients with an enlarged RV and increased PAP values, there were significantly increased levels of BNP, while the values of TnI and hsCRP were not associated with the parameters of the RV function. After adjusting the effects of certain cofounders, beside BNP and TnI, PAP was also distinguished as a strong and independent predictor. The increasing value of this marker for $1 \mathrm{mmHg}$ increases the risk of death by $8.7 \%$. Recently, Bistol et al. (21) have pointed out the prognostic significance of simultaneous evaluation of RV using tissue Doppler and evaluation of BNP concentration.

Our results could be very important in the clinical practice for distinguishing cardiogenic from respiratory dyspnea early during hospitalization. In a recent study, Meyer et al. (22) have demonstrated that dysfunction of the RV was an independent predictor of mortality in patients with systolic HF but not in the population over 75 years old. 
It is crucial to perform simultaneous procedures which include the determination of the level of BNP, TnI and echocardiographic assessment of the RV function which will allow faster distinction of the patients with AHF (left-sided and right-sided AHF), better clinical assessment and better prognosis. The task for the future researches is to understand this syndrome better, which will help improve the diagnostic and therapeutic strategies of AHF in admission cardiology units and during early hospitalization.

\section{CONCLUSION}

The results of this study pointed to the importance of combining echocardiography with biomarker assessments of pathophysiological AHF mechanisms during the early phase of hospitalization.

The values of $\mathrm{BNP} \geq 1062.04 \mathrm{pg} / \mathrm{ml}, \mathrm{PAP} \geq 44.5$
$\mathrm{mmHg}$ and $\mathrm{TnI} \geq 0.04 \mathrm{ng} / \mathrm{ml}$ were associated with the high mortality risk.

Our results showed that BNP, PAP and TnI are strong and independent predictors of one-year mortality in patients hospitalized with acute heart failure.

\section{Acknowledgments}

None

\section{Conflicts of interest}

The authors have no conflicts of interest relevant to this article.

\section{Funding/Support Statement}

None

\section{References}

1. ESC Guidelines for the diagnosis and treatment of acute and chronic heart failure 2016. Eur Heart J 2016; 18(8): 891-975.

https://doi.org/10.1002/ejhf.592

2. Petrović D, Deljanin Ilić M, Stojanović S. Prognostic value of biomarkers and co-morbidities in patients with acute heart failure: one-year follow-up study. Srp Arh Celok Lek 2017; 145(3-4):118-23. https://doi.org/10.2298/SARH160225030P

3. Maggioni A, Dahlström U, Filippatos G, et al. EUR Observational Research Programme: regional differences and 1-year follow-up results of the Heart Failure Pilot Survey (ESC-HF Pilot). Eur Heart J 2013; 15: 808-17. https://doi.org/10.1093/eurihf/hft050
4. Hobbs FDR, Jones MI, Allan TF, et al. European survey of primary care physician perceptions on heart failure diagnosis and management (Euro-F). Eur Heart J 2000; 21: 1877-87. https://doi.org/10.1053/euhj.2000.2170

5. Mueller C, Scholer A, Laule-Kilian K, et al. Use of B-type natriuretic peptide in the evaluation and management of acute dyspnea. N Engl J Med 2004;350:647-54. https://doi.org/10.1056/NEJMoa031681

6. Harjola VP, Follath F, Nieminen MS, et al. Characteristics, outcomes, and predictors of mortality at 3 months and 1 year in patients hospitalized for acute heart failure. Eur J Heart Fail 2010; 12: 239-48. https://doi.org/10.1093/eurihf/hfq002 
7. Kenneth D, Gerasimos F, Piotr P, et al. ESC guidelines for the diagnosis and treatment of acute and chronic Heart Failure 2008. Eur J Heart Failure 2008; 10: 933-89.

https://doi.org/10.1016/j.ejheart.2008.08.005

8. Mendes LA, Dec GW, Picard MH, et al. Right ventricular dysfunction: an independent predictor of adverse outcome in patients with myocarditis. Am Heart J 1994; 128: 301-7. https://doi.org/10.1016/0002-8703(94)90483-9

9. ESC Guidelines for the diagnosis and treatment of acute and chronic heart failure. Eur Heart J 2012; 33: 1787-847.

https://doi.org/10.1093/eurhearti/ehs104

10. Lang RM, Badano LP, Mor-Avi V, et al. Recommendations for cardiac chamber quantification by echocardiography in adults: an update from the American Society of Echocardiography and the European Association of Cardiovascular Imaging. Eur Heart J Cardiovasc Imaging 2015; 16: 233-70.

https://doi.org/10.1093/ehjci/jev014

11. Petrovic D, Deljanin Ilic M, Ilic S, at al. Prognostic significance of B-type natriuretic peptide and pulmonary arterial pressure in patients with acute heart failure. Eur J Heart Failure 2017; 19 (Suppl. S1): 392.

12. Siirila-Waris K, Lassus J, Melin J, et al. Characteristics, outcomes, and predictors of 1-year mortality in patients hospitalized for acute heart failure. Eur Heart J 2006; 27: 3011-7.

https://doi.org/10.1093/eurheartj/ehl407

13. Bosseau C, Galli E, Donal E. Prognostic value of BNP in heart failure with preserved or reduced EF. Heart 2015; 101(23): 1855-6.

https://doi.org/10.1136/heartinl-2015-308515

14. Peacock WF, De Marco T, Fonarow GC, et al. Cardiac troponin and outcome in acute heart failure. N Engl J Med 2008; 358(20): 2117-26. https://doi.org/10.1056/NEJMoa0706824

15. Araújo JP, Lourenço P, Azevedo A. Prognostic value of high-sensitivity $\mathrm{C}$-reactive protein in heart failure: a systematic review. J Card Fail 2009; 15:256-66.

https://doi.org/10.1016/j.cardfail.2008.10.030

16. O'Connor CM, Stough WG, Gallup DS, et al. Demographics, clinical characteristics, and outcomes of patients hospitalized for decompensated heart failure: observations from the IMPACT-HF registry. J Card Fail 2005;11(3):200-5. https://doi.org/10.1016/j.cardfail.2004.08.160

17. Burke MA, Katz DH, Beussink L, et al. Prognostic importance of pathophysiologic markers in patients with heart failure and preserved ejection fraction. Circ Heart Fail 2014; 7(2): 288-99.

https://doi.org/10.1161/CIRCHEARTFAILURE.113. $\underline{000854}$

18. Vincent FMS, Dirk LB, Gilles WDeK. Pulmonary hypertension and right heart failure in heart failure with preserved left ventricular ejection fraction: pathophysiology and natural history. Curr Opin Cardiol 2012, 27: 273-80. https://doi.org/10.1097/HCO.0b013e3283512035

19. Vogelsang TW, Jensen RJ, Monrad AL, et al. Independent effects of both right and left ventricular function on plasma brain natriuretic peptide. Eur J Heart Fail 2007; 9: 892-6.

https://doi.org/10.1016/j.ejheart.2007.05.015

20. Mariano-Goulart D, Eberlé MC, Boudousq V, et al. Major increase in brain natriuretic peptide indicates right ventricular systolic dysfunction in patients with heart failure. Eur J Heart Fail 2003; 5: 481-8. https://doi.org/10.1016/S1388-9842(03)00041-2

21. Bistola V, Parissis JT, Paraskevaidis I, et al. Prognostic value of tissue Doppler right ventricular systolic and diastolic dysfunction indexes combined with plasma B type natriuretic peptide in patients with advanced heart failure secondary to ischemic or idiopathic dilated cardiomyopathy. Am J Cardiol 2010; 105: 249-54.

https://doi.org/10.1016/j.amjcard.2009.08.682

22. Meyer P, Desai R, Mujib M, et al. Right ventricular ejection is an independent predictor of mortality but not of hospitalization in older systolic heart failure patients. Int J Cardiol. 2012; 155(1): 120-5. https://doi.org/10.1016/j.ijcard.2011.05.046 


\title{
Prognostički značaj dijametra desne komore, plućnog arterijskog pritiska i biomarkera kod bolesnika sa akutnom srčanom insuficijencijom
}

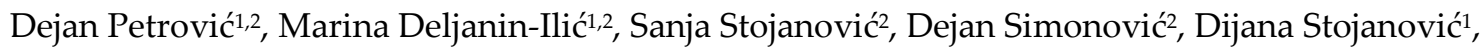 \\ Valentina Mitić ${ }^{2}$ Milovan Stojanović \\ ${ }^{1}$ Univerzitet u Nišu, Medicinski fakultet, Niš, Srbija \\ 'Institut za lečenje i rehabilitaciju "Niška Banja", Niška Banja, Srbija
}

\section{S A ŽETAK}

Cilj studije bio je proceniti prognostički značaj dijametra desne komore, plućnog arterijskog pritiska (PAP) i biomar-kera: natriuretski peptid tipa B (BNP), troponin I (TnI) i C-reaktivni protein visoke osetljivosti (hsCRP), na jednogodišnji mortalitet kod bolesnika sa akutnom srčanom insuficijencijom (ASI).

Studija je obuhvatila ukupno 225 bolesnika (pts) (prosečne starosti 70,29 godina $\pm 9,74$ godine) koji su primljeni na odelenje intenzivne nege zbog znakova i simptoma ASI. Vrednosti svih standardnih biohemijskih parametara i BNP, Tnl i hsCRP određene su tokom prva 24 sata nakon prijema. Svim bolesnicima urađen je ehokardiografski pregled.

Tokom jednogodišnjeg praćenja umrlo je $78(34,70 \%)$ bolesnika. U poređenju sa grupom preživelih (n $=147)$, bolesnici iz grupe umrlih imali su veće vrednosti BNP $(853,10 \mathrm{pg} / \mathrm{ml} \pm 384,92 \mathrm{pg} / \mathrm{ml}$ naspram 1399,68 $\mathrm{pg} / \mathrm{ml} \pm 464,44 \mathrm{pg} / \mathrm{ml}, \mathrm{p}<0,001), \mathrm{TnI}(0,59 \mathrm{ng} / \mathrm{ml} \pm 2,04 \mathrm{ng} / \mathrm{ml}$ naspram 2,00 ng/ml $\pm 8,29 \mathrm{ng} / \mathrm{ml}, \mathrm{p}<0,05)$, dijametra desne komore i PAP $(p<0,001)$. BNP je pozitiv-no korelirao sa TnI $(\varrho=0,311)$, PAP $(\varrho=0,255)$ i dijametrom desne komore ( $\varrho=0,304, p<0,001)$. Vrednosti $B N P \geq 1062,04 \mathrm{pg} / \mathrm{ml}, \mathrm{PAP} \geq 44,5 \mathrm{mmHg}$ i TnI $\geq 0,04$ $\mathrm{ng} / \mathrm{ml}$ bile su povezane sa većim rizikom od smrti.

Naši rezultati pokazali su to da su BNP, PAP i TnI snažni i nezavisni prediktori jednogodišnjeg mortaliteta kod hospitalizovanih pacijenata sa akutnom srčanom insuficijencijom.

Ključne reči: akutna srčana insuficijencija bolesnika, biomarkeri, plućni arterijski pritisak, dijametar desne komore 